\title{
ESTIMATION OF SOYBEAN GENETIC PROGRESS IN THE SOUTH OF BRAZIL USING MULTI- ENVIRONMENTAL YIELD TRIALS
}

\author{
Cláudia Erna Lange ${ }^{*}$; Luiz Carlos Federizzi² \\ Instituto Rio Grandense do Arroz/Setor de Agronomia, Av. Bonifácio Carvalho Bernardes, 1494 - $94930-030$ - \\ Cachoeirinha, RS - Brasil. \\ ${ }^{2}$ UFRGS/Faculdade de Agronomia, Depto. de Plantas de Lavoura, Av. Bento Gonçalves, 7712 - 91501-970 - \\ Porto Alegre, RS - Brasil. \\ *Corresponding author <claudia-lange@irga.rs.gov.br>
}

\begin{abstract}
The success of a genetic breeding program in a certain period can be assessed by the genetic gain observed. Genetic progress can be estimated from the multi environmental trials (MET) data which are routinely carried out by annual species breeding programs for the assessment of new commercial cultivars. A data set of 20 years of MET of advanced soybean lines derived from four breeding programs was used to estimate and to compare the genetic gains obtained for three soybean maturity groups (early, medium and late) in four cropping regions of the State of Rio Grande do Sul. The estimated yield gains ranged from 0.0 to $71.5 \mathrm{~kg} \mathrm{ha}^{-1}$ year $^{-1}$ (3.49\% per year), depending on the maturity group and region, which suggests that the genetic breeding effort does not have a similar effect among the maturity groups or benefit the regions equally. There was no evidence of genetic progress for the early maturity group in any of the four regions, whereas gains in Regions I and IV were comparatively greater than those in Regions II and III. The objectives of the soybean breeding program in the region should be redirected. Since not all the experimental lines used to estimate genetic gains were commercially released, the reported genetics gains were achieved by the breeding programs rather than those achieved by the cropping systems.
\end{abstract}

Key words: Glycine $\max (\mathrm{L}$.) Merrill, genetic gain, maturity groups, advanced lines

\section{ESTIMATIVA DO PROGRESSO GENÉTICO EM SOJANO SULDO BRASIL APARTIR DE RESULTADOS DE EXPERIMENTOS DE RENDIMENTO}

RESUMO: O sucesso de um programa de melhoramento durante um determinado período pode ser avaliado pelo ganho genético alcançado. Progresso genético pode ser estimado a partir de dados resultantes dos ensaios de avaliação de genótipos realizados rotineiramente em vários locais pelos programas de melhoramento de espécies anuais para fins de lançamento de novas cultivares comerciais. Os resultados de rendimento de grãos de 20 anos de experimentos de avaliação de linhagens derivadas de quatro programas de melhoramento de soja foram usados para estimar e comparar os ganhos genéticos obtidos em três grupos de maturação (precoce, médio e tardio) e em quatro regiões de cultivo do Estado do Rio Grande do Sul (Brasil). Os ganhos estimados variaram de zero a 71,5 $\mathrm{kg} \mathrm{ha}^{-1}$ ano $^{-1}(3,49 \%$ ao ano), dependendo do grupo de maturação e da região. Não foi detectado avanço genético para o grupo precoce em nenhuma das quatro regiões. Os ganhos obtidos nas regiões I e IV foram maiores que os das regiões II e III. Os esforços dos programas de melhoramento genético não refletiram de forma equivalente entre os grupos de maturação e não beneficiaram igualmente as regiões produtoras, indicando que os objetivos do melhoramento de soja no Estado devem ser reavaliados. Os ganhos estimados neste trabalho podem ser diferentes dos vivenciados pelos produtores rurais, uma vez que nem todas as linhagens experimentais que geraram os dados do presente estudo foram lançadas comercialmente.

Palavras-chave: Glycine $\max (\mathrm{L}$.) Merrill, ganho genético, grupos de maturação, linhas avançadas

\section{INTRODUCTION}

The success of a genetic breeding program in a certain period can be assessed by the genetic gain ob- served. The estimated increase in soybean yield due to genetic improvement ranged from 0.5 to $1.2 \%$ per year in the United States (Boerma, 1979; Specht \& Williams, 1984; Uston et al., 2001), in India (Karmakar \& 
Bhatnagar, 1996) and in Canada (Voldeng et al., 1997). In Brazil, estimates of genetic progress for soybean yield in the States of Paraná and Rio Grande do Sul have shown that, depending on the maturity group, there was either an increase or a reduction in the yield potential (Toledo et al., 1990; Alliprandini et al., 1993; Rubin, 1995).

Besides quantifying the progress obtained in a certain period, the genetic gain analysis also enables aggregation of other information, such as comparison of the gains obtained with the use of different breeding strategies or in different environments (Specht \& Williams, 1984). This kind of information contributes to the understanding of past events, allows elaboration of new strategies, adoption of corrective methods and more efficient resource allocation that together result in an increase in the breeding programs efficacy.

Genetic progress can be estimated from the multi environmental trials (MET) data (Vencovsky et al., 1988; Toledo et al., 1990; Breseghello et al., 1998; St. Martin \& McBlain, 1991), which are routinely carried out by annual species breeding programs for the assessment of new commercial cultivars. From the $1979 / 80$ to the $1998 / 99$ growing seasons, the best soybean lines from all of the Rio Grande do Sul breeding programs were assessed in yield trials that included the different cropping regions of the State. The objectives of these studies were to quantify the genetic gain of soybean grain yield of tree maturity group during twenty years Rio Grande do Sul and to verify if the four cropping regions of the State were equally benefited by the breeding effort.

\section{MATERIAL AND METHODS}

Regions - Rio Grande do Sul is the Southernmost State of Brazil. It is located between parallels $27^{\circ} 05^{\prime}$ and $33^{\circ} 45^{\prime}$ South (Figure 1). Its climate is classified as wet subtropical and there are four distinct regions for soybean cropping. Region I is the preferred region for soybean cultivation because there are no climatic restrictions in the majority of the years. Region II historically experiences drought in the periods between sowing and crop establishment, and later between flowering, pod formation and the onset of pod filling. Regions III and IV present restrictions to cropping late maturity genotypes because of periods with heavy rain during harvest and due to low temperatures in the pod filling periods, respectively (Figure 1) (Berlato, 1981).

Data - Genetic gain of soybean grain yield was estimated from the trials "Final Assessment of Soybean Lines and Cultivars" conducted between the 1979/80 and the 1998/99 growing seasons, at several locations in the four soybean cropping regions of the State. The trials were conducted by the following institutions: Fundacep Fecotrigo (previously Research and Experimentation Center Fecotrigo), Fepagro (previously Ipagro), Embrapa- Wheat Research National Center, Embrapa- Lowlands Research National Center and by the private breeding company OR Seeds. The geographical coordinates of the counties where the trials were conducted are presented in the Table 1. The following breeding programs contributed with experimental cultivars: Fundacep Fecotrigo, Fepagro, EmbrapaWheat Research National Center, Embrapa- Lowlands Research National Center and by Francisco Terasawa, a private breeding company from Paraná State. The four regions were not equally represented in the trials (Table 2). Region I, which accounted for the largest number of trial locations in each year, had the largest soybean production area and is where Fundacep Fecotrigo's, Fepagro's and Embrapa- Wheat Research National Center's breeding programs are located. Region IV was the least represented in the trials.

Data from trials with a coefficient of variation (CV) greater than $20 \%$ were discarded, once large CV is often associated with increased experimental variability. Consequently, genetic gain estimates were obtained from a variable number of years (from five years for the medium and late maturity groups in Region IV, to 19 years for the late maturity group in Region I), which covered different periods (from 1993 to 1999 for the medium maturity group in Region IV and from 1980 to 1999 for the early group in Region I and medium and late groups in Region I, II and III) (Table 2).

The number of years in which each genotype was assessed varied from one to three, except for the

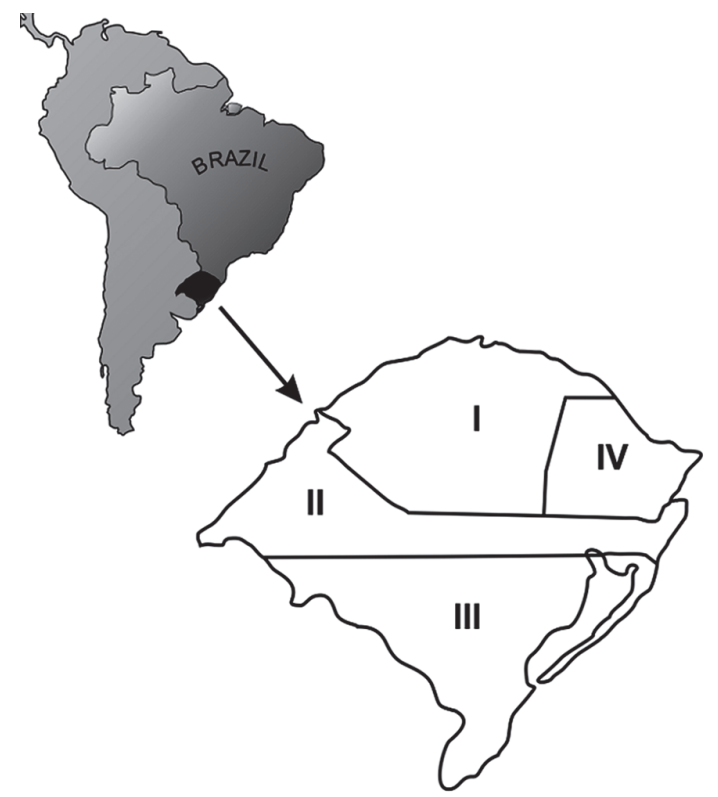

Figure 1 - Map of Rio Grande do Sul showing soybean cropping regions. 
Table 1 - Counties were the trials "Final Assessment of Soybean Lines and Cultivars" were conducted between the 1979/80 and the 1998/99 and its respective geographical coordinates.

\begin{tabular}{|c|c|c|}
\hline County & Latitude & Longitude \\
\hline Santo Augusto & $2751^{\prime} 05.23^{\prime \prime} \mathrm{S}$ & 53 46'37. 95'"W \\
\hline Santa Rosa & $2752^{\prime} 15.54^{\prime \prime} \mathrm{S}$ & $54^{\circ} 26^{\prime} 36.07^{\prime \prime} \mathrm{W}$ \\
\hline Palmeira das Missões & $27^{\circ} 53^{\prime} 54.99^{\prime \prime} \mathrm{S}$ & $53^{\circ} 18^{\prime} 50.21^{\prime \prime} \mathrm{W}$ \\
\hline Giruá & $28^{\circ} 01^{\prime} 42.35^{\prime \prime} \mathrm{S}$ & $54^{\circ} 21^{\prime} 01.41^{\prime \prime} \mathrm{W}$ \\
\hline Coxilha & $28^{\circ} 07^{\prime} 50.16^{\prime \prime} \mathrm{S}$ & $52^{\circ} 17^{\prime} 25.11^{\prime \prime} \mathrm{W}$ \\
\hline Passo Fundo & $28^{\circ} 15^{\prime} 40.19^{\prime \prime} \mathrm{S}$ & $52^{\circ} 24^{\prime} 30.01^{\prime \prime} \mathrm{W}$ \\
\hline Cruz Alta & $28^{\circ} 38^{\prime} 24.40^{\prime \prime} \mathrm{S}$ & $53^{\circ} 36^{\prime} 31.99^{\prime \prime} \mathrm{W}$ \\
\hline Santo Ângelo & $28^{\circ} 18^{\prime} 01.07^{\prime \prime} \mathrm{S}$ & $54^{\circ} 15^{\prime} 48.63^{\prime \prime} \mathrm{W}$ \\
\hline São Luis Gonzaga & $28^{\circ} 24^{\prime} 30.57^{\prime \prime} \mathrm{S}$ & $54^{\circ} 57^{\prime} 40.70^{\prime \prime} \mathrm{W}$ \\
\hline Vacaria & $28^{\circ} 30^{\prime} 38.41^{\prime \prime} \mathrm{S}$ & $50^{\circ} 55^{\prime} 47.23^{\prime \prime} \mathrm{W}$ \\
\hline Augusto Pestana & $28^{\circ} 31^{\prime} 01.58^{\prime \prime} \mathrm{S}$ & $53^{\circ} 59^{\prime} 38.87^{\prime \prime} \mathrm{W}$ \\
\hline Tapera & $28^{\circ} 37^{\prime} 33.97^{\prime \prime} \mathrm{S}$ & $52^{\circ} 52^{\prime} 11.52^{\prime \prime} \mathrm{W}$ \\
\hline Ibirubá & $28^{\circ} 37^{\prime} 47.56^{\prime \prime} \mathrm{S}$ & $53^{\circ} 05^{\prime} 25.44^{\prime \prime} \mathrm{W}$ \\
\hline São Borja & $28^{\circ} 40^{\prime} 58.60^{\prime \prime} \mathrm{S}$ & $55^{\circ} 58^{\prime} 38.99^{\prime \prime} \mathrm{W}$ \\
\hline Veranópolis & $28^{\circ} 54^{\prime} 02.42^{\prime \prime} \mathrm{S}$ & $51^{\circ} 33^{\prime} 10.26^{\prime \prime} \mathrm{W}$ \\
\hline Júlio de Castilhos & $29^{\circ} 13^{\prime} 36.92^{\prime \prime S}$ & $53^{\circ} 40^{\prime} 56.65^{\prime \prime} \mathrm{W}$ \\
\hline Taquari & $29^{\circ} 48^{\prime} 01.52^{\prime \prime} \mathrm{S}$ & $51^{\circ} 51^{\prime} 52.27^{\prime \prime} \mathrm{W}$ \\
\hline Eldorado do Sul & $30^{\circ} 05^{\prime} 08.39^{\prime \prime} \mathrm{S}$ & $51^{\circ} 37^{\prime} 04.65^{\prime \prime} \mathrm{W}$ \\
\hline Camaquã & $30^{\circ} 51^{\prime} 05.37^{\prime \prime} \mathrm{S}$ & $51^{\circ} 48^{\prime} 46.39^{\prime \prime} \mathrm{W}$ \\
\hline Pelotas & $31^{\circ} 46^{\prime} 33.72^{\prime \prime} \mathrm{S}$ & $52^{\circ} 21^{\prime} 33.72^{\prime \prime} \mathrm{W}$ \\
\hline Piratini & $31^{\circ} 26^{\prime} 31.68^{\prime \prime} \mathrm{S}$ & $53^{\circ} 06^{\prime} 16.28^{\prime \prime} \mathrm{W}$ \\
\hline Capão do Leão & $31^{\circ} 46^{\prime} 02.96^{\prime \prime} \mathrm{S}$ & $52^{\circ} 26^{\prime} 55.37^{\prime \prime} \mathrm{W}$ \\
\hline Pedro Osório & $31^{\circ} 51^{\prime} 51.86^{\prime \prime} \mathrm{S}$ & $52^{\circ} 49^{\prime} 17.72^{\prime \prime} \mathrm{W}$ \\
\hline Jaguarão & $32^{\circ} 34^{\prime} 00.35^{\prime \prime} \mathrm{S}$ & $53^{\circ} 22^{\prime} 34.94^{\prime \prime} \mathrm{W}$ \\
\hline Santa Vitória do Palmar & $33^{\circ} 31^{\prime} 10.36^{\prime \prime} \mathrm{S}$ & $53^{\circ} 22^{\prime} 02.25^{\prime \prime} \mathrm{W}$ \\
\hline
\end{tabular}

Table 2 - Number of genotypes, locations, years and period included in the analysis of genetic progress by maturity group and cropping region.

\begin{tabular}{|c|c|c|c|c|c|}
\hline Cropping region & Maturity group & Number of genotypes & Number of locations & Number of years & Period \\
\hline \multirow{3}{*}{ I } & Early & 102 & 13 & 18 & 1980 a 1999 \\
\hline & Medium & 135 & 13 & 18 & 1980 a 1999 \\
\hline & Late & 128 & 15 & 19 & 1980 a 1999 \\
\hline \multirow{3}{*}{ II } & Early & 94 & 3 & 14 & 1980 a 1997 \\
\hline & Medium & 127 & 3 & 16 & 1980 a 1999 \\
\hline & Late & 120 & 3 & 15 & 1980 a 1999 \\
\hline \multirow{3}{*}{ III } & Early & 96 & 5 & 15 & 1981 a 1999 \\
\hline & Medium & 116 & 6 & 14 & 1980 a 1999 \\
\hline & Late & 96 & 4 & 13 & 1980 a 1999 \\
\hline \multirow{3}{*}{ IV } & Early & 52 & 2 & 6 & 1980 a 1996 \\
\hline & Medium & 42 & 1 & 5 & 1993 a 1999 \\
\hline & Late & 53 & 2 & 5 & 1980 a 1997 \\
\hline
\end{tabular}

control cultivars, which remained for longer periods.

Statistical analyses - The estimated genetic progress was obtained following Breseghello et al. (1998), and used the yield means of the genotypes in the trials at each location. The analyses were performed separately for the early, medium, and late maturity groups (spanning maturity groups from VI to VIII), and for each of the four State regions. Data from genotypes that were missing in one or more locations within a year were not used in the analysis.

The following model of analysis was used:

$Y_{i j k}=\mu+A_{k}+L / A_{j k}+G_{i}+\varepsilon_{i j k}$

where, $Y_{i j k}$ is the yield mean of the $i^{\text {th }}$ genotype in the 
$j^{\text {th }}$ location in $k^{\text {th }}$ year; $\mu$ is the general mean; $A_{k}$ is the year effect, which ranges from 1 to $k ; L / A_{j k}$ is the location within year effect, which ranges from 1 to $j$ in each year; $G_{i}$ is the genotype effect, which ranges from 1 to $i ; \varepsilon_{i j k}$ is the error associated with each $Y_{i j k}$ mean.

Genotype grain yield means from each location within each year were used in place of the replication values within each location and year. This decreased the size of the matrices analyzed, especially the variance and covariance matrix, and reduced the computational requirements. This consideration was especially relevant in this study, where a large amount of data was used. In contrast, the calculation of the error sum of the squares (RSS) lost the component due to the term replication $\times$ location $\times$ year, which normally presents low values and large degrees of freedom. In cases where the trial error mean squares or the coefficient of variation and the general mean of the trial were available, the error term of each trial could be included in the analysis and the precision of the estimates recovered (Breseghello et al., 1998). In the absence of these data, it was assumed that the genotype means of the trials derived from the same population of observations and had equal variance. The fact that only trial data with a variation coefficient less than $20 \%$ were used supports this assumption.

The analyses of variance were performed in the IML module of the SAS statistical package (SAS Institute, 1985), using the generalized least squares method. The genotypic mean vectors adjusted for the location and year model effects were obtained from the multiplication of the $\mathbf{C}$ coefficients matrices by the solution vectors $\left(\hat{\theta}^{\circ}\right)$ obtained in the analyses of variance. The $\mathbf{C}$ coefficient matrices were constructed according to Breseghello et al. (1998); however, in this study, the terms replication $\times$ location and replication $\times$ year were not considered. Thus, the number of lines corresponded to the total number of entries (yield mean of each genotype in each location and each year) and the number of columns corresponded to the total number of terms of the model.

The variance and covariance matrices of the means adjusted to the model effects $(\hat{\mathrm{V}}(\hat{\mathrm{V}}))$ were obtained by the formula:

$\hat{\mathrm{V}}(\hat{\mathrm{Y}})=\mathbf{C}\left(\mathbf{X}^{\prime} \cdot \mathbf{X}\right)^{\mathbf{G}} \cdot \mathbf{C}^{\prime} \cdot \mathrm{RMS}$

where $\mathbf{X}$ is the design matrix obtained from the statistical model and RMS is the error least square from the analysis of variance of the model.

Genetic gain estimate - for each year of analysis, the mean yield was calculated from the genotypes presented in the experiments. An S matrix was constructed, where each line corresponded to a single year of analysis and each column to a single genotype (Breseghello et al., 1998). The vector of the mean yields at each assessment year $\left(\hat{\mathrm{Y}}^{*}\right)$ was obtained by the multiplication:

$\hat{\mathrm{Y}}^{*}=\mathbf{S} \cdot \hat{\mathrm{Y}}$

The variance and covariance matrix were obtained by the formula:

$\hat{\mathrm{V}}\left(\hat{\mathrm{Y}}^{*}\right)=\mathbf{S} \cdot \hat{\mathrm{V}}(\hat{\mathrm{Y}}) \cdot \mathbf{S}^{\prime}$.

The regression coefficient of the mean annual yield $\hat{\beta}$ in function of the year, obtained by generalized least squares, estimated the annual genetic gain:

$\hat{\beta}=\left(\mathbf{x}^{\prime} \mathbf{D}^{-1} \mathbf{x}\right)^{-1}$. $\left(\mathbf{x}^{\prime} \mathbf{D}^{-1} \hat{Y}^{*}\right)$.

where $\mathrm{x}$ is the design matrix constructed by the regression model of mean annual yield in function of the year.

The variance and covariance matrix of the intercept and the linear regression coefficient were obtained by the following equation:

$\hat{\mathrm{V}}(\hat{\beta})=\left(\mathbf{D}^{-1} \mathbf{x}\right)^{-1}$.

The significance of the regression coefficient was tested by the t-test. The relative genetic gain was obtained by dividing the annual genetic gain by the yield average of the first year.

The correlations among the estimated annual mean yield for the four soybean cropping regions in the State were calculated to investigate whether the gains obtained in each region were associated with the gains in the other regions.

\section{RESULTS}

The 20-year mean yields of the three maturity groups values were not very different, which indicates that their genetic yield potentials did not differ (Figure $2 \mathrm{~A})$. In contrast, the 20 years soybean mean yield of Region I was much higher than the means of the other cropping regions of the State, indicating that Region I presented more favorable conditions for soybean cropping or that the genotypes are more adapted for this region (Figure 2B). All maturity groups presented greater yield means in Region I than in the other regions, which confirmed this region as the preferential environment for soybean cultivation in the State (Figure $2 \mathrm{C}$ ). The interaction between maturity groups and regions was important (Figure 2C), and, for Region II, the later maturity group has a better yield average than do the other groups. For Regions II, III and IV, the early and medium maturity groups yielded slightly better than the late group. 
The genetic gains estimated varied with the maturity groups and regions. In Region I, genetic progress of 34.6 and $26.8 \mathrm{~kg} \mathrm{ha}^{-1}$ year $^{-1}$ was estimated for the medium and late maturity groups, respectively; whereas the early maturity group did not present gains (Table 3). Thus, there was a change in the rank of the groups regarding their mean yield performance over the 20 years of the study. The early maturity group yield, which was highest at the beginning of the 1980s, was kept stable and was supplanted by the medium and late maturity group yield, which presented gains in the period (Table 3).

In Region II, only the medium maturity group showed significant yield progress, estimated at 18.5 $\mathrm{kg} \mathrm{ha}^{-1}$ year $^{-1}$. Consequently, the yield of the group increased $350 \mathrm{~kg} \mathrm{ha}^{-1}$ in the period, reaching the level of the late maturity group, which is the one with the best yield performance in this region (Figure 2C). The early maturity group did not present gains, and maintained its yield level in the period, which was the worst among the three maturity group for Region II (Table $3)$.

In Region III, a yield mean increase of 20.1 $\mathrm{kg} \mathrm{ha}^{-1}$ year $^{-1}$ was estimated only for the late maturity group. The mean yield of this maturity group surpassed the mean of the intermediate group and was close to that of the early maturity group (Table 3 ). What was unexpected once late maturity group genotypes in Region III presented a higher risk of loss due to rain at harvest (Berlato, 1981).

Increases in yield of 71.0 and $18.1 \mathrm{~kg} \mathrm{ha}^{-1}$ year $^{-1}$ in Region IV were detected for the medium and
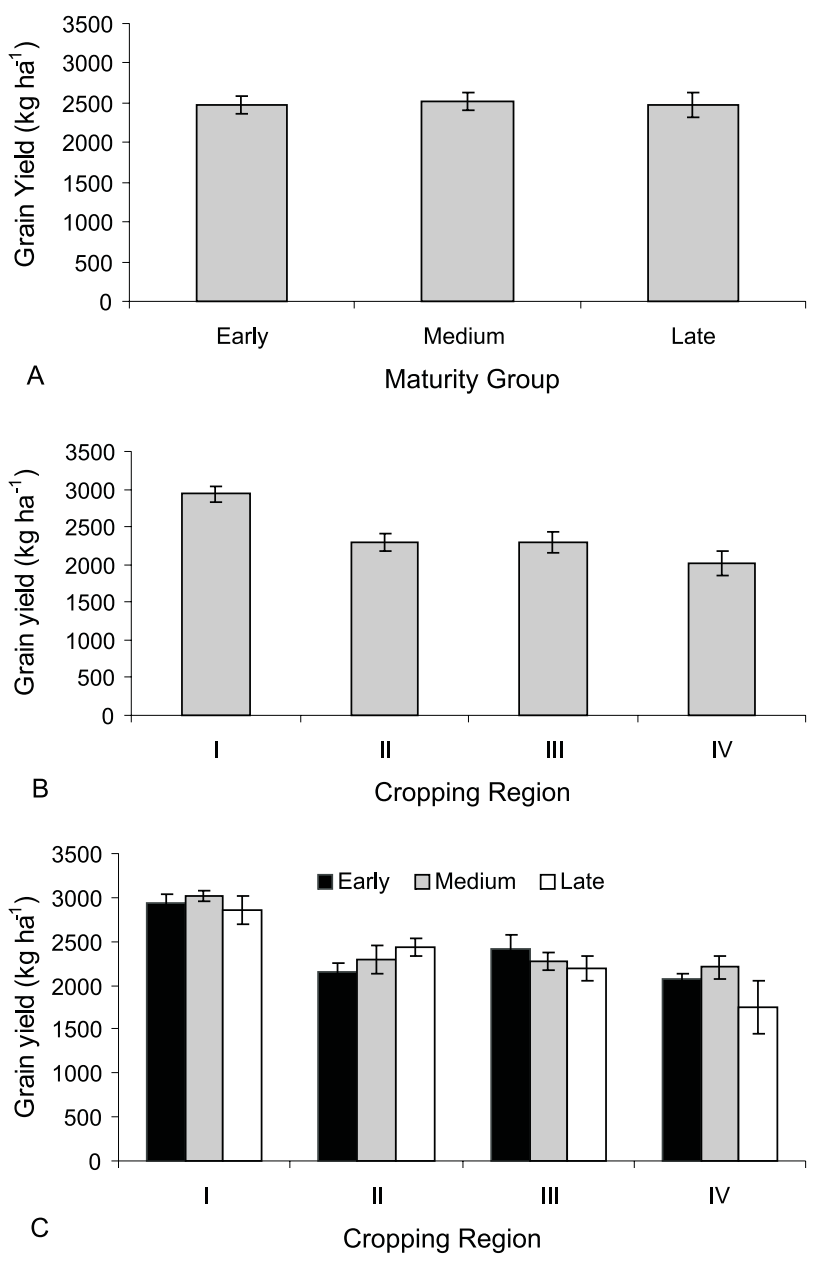

Figure 2 - Twenty year yield means obtained in the Final Soybean Yield Trials involving inbred lines and cultivars by maturity groups (A), cropping regions (B) and both (C).

Table 3 - Annual and relative genetic gains, and mean initial and final yield per maturity group and cropping region.

\begin{tabular}{|c|c|c|c|c|c|c|}
\hline \multirow{2}{*}{ Cropping region } & \multirow{2}{*}{ Maturity group } & \multirow{2}{*}{ Genetic Gain } & \multirow{2}{*}{$t$-test } & \multirow{2}{*}{ Genetic Gain } & \multicolumn{2}{|c|}{ Grain yield } \\
\hline & & & & & Start & Final \\
\hline \multirow{4}{*}{ I } & & $\mathrm{kg} \mathrm{ha}^{-1}$ year $^{-1}$ & & \multicolumn{3}{|c|}{ ng ha-1 $\ldots$} \\
\hline & Early & 6.4 & NS & - & 2871 & 2993 \\
\hline & Medium & 34.6 & $* * *$ & 1.27 & 2728 & 3286 \\
\hline & Late & 26.8 & $* * *$ & 1.03 & 2598 & 3108 \\
\hline \multirow{3}{*}{ II } & Early & 3.7 & NS & - & 2122 & 2185 \\
\hline & Medium & 18.5 & $*$ & 0.87 & 2120 & 2470 \\
\hline & Late & 5.1 & NS & - & 2393 & 2490 \\
\hline \multirow{3}{*}{ III } & Early & 6.3 & NS & - & 2355 & 2468 \\
\hline & Medium & 0.27 & NS & - & 2270 & 2275 \\
\hline & Late & 20.1 & $* *$ & 1.01 & 1997 & 2379 \\
\hline \multirow{3}{*}{ IV } & Early & 2.4 & NS & - & 2043 & 2081 \\
\hline & Medium & 71.5 & $*$ & 3.49 & 2048 & 2403 \\
\hline & Late & 18.1 & $*$ & 1.15 & 1579 & 1886 \\
\hline
\end{tabular}

NS - not significantly different from zero. ***Different from zero at the $1 \%$ level of probability. $* *$ Different from zero at the $5 \%$ level of probability. *Different from zero at the $10 \%$ level of probability. 
late maturity groups, respectively. The estimates obtained for the medium group refer only to the period between the 1992/93 and 1998/99 growing seasons (Table 2). Therefore, the estimate is based on a reduced sample; consequently, its accuracy may be lower than the estimates of the other maturity groups and regions and should be viewed with caution. Although the cultivation of late maturity varieties in Region IV presented restrictions due to the greater risk of frost during the pod filling stage (Berlato, 1981), the genotypes in this group increased the mean yield by $326 \mathrm{~kg} \mathrm{ha}^{-1}$ in the period analyzed and are quickly approaching the yield level presented by the early maturity group (Table 3 ).

\section{DISCUSSION}

The genetic gains in yield attained by different crops should be compared based on the relative gain, because the energy requirements for grain formation vary greatly between species. Compared with cereal crops, soybean grain presents a high concentration of protein and oil and a low concentration of starch. The synthesis of one gram of oil and protein requires more photo-assimilates than does the production of the same quantity of starch. In this study, the estimated relative genetic gain ranged from $0.87 \%$ for the medium maturity group in Region II to $3.49 \%$ for the same group in Region IV, but most of the values were between 1.01 and $1.27 \%$ (Table 3 ). The relative gain values detected in this study are similar to those reported for annual crops that do not produce much oil or protein, such as rice (Breseghello et al., 1999; Soares et al., 1999; Peng et al., 2000) and wheat (Cox et al., 1988).

Previous studies also indicated different genetic gains for yield in the different maturity groups. In Paraná State, gains of 45 (Toledo et al., 1990) and 24 $\mathrm{kg} \mathrm{ha}^{-1}$ year $^{-1}$ (Alliprandini et al., 1993) were estimated for the early group between 1981 and 1986 and 1986 and 1990, respectively; for the semi-early group, the gains in the same periods were 37 (Toledo et al., 1990) and $11 \mathrm{~kg} \mathrm{ha}^{-1}$ year $^{-1}$ (Alliprandini et al., 1993). For the medium maturity group, there was a loss in yield of $8 \mathrm{~kg} \mathrm{ha}^{-1}$ year $^{-1}$ (Alliprandini et al., 1993) between 1986 and 1990. In Rio Grande do Sul, the genetic improvement for soybean yield of the late group obtained from the 1950s to the $1990 \mathrm{~s}$ was estimated at $23 \mathrm{~kg}$ $\mathrm{ha}^{-1}$ year $^{-1}$; whereas no significant gains were detected for the early and intermediate maturity groups in the same time period (Rubin, 1995).

The absence of genetic progress for the early maturity group may be the consequence of breeders' priorities during the 1970s and 1980s. In this period, efforts were concentrated on altering traits that would increase adaptation of the early maturity group genotypes to the cropping conditions in Rio Grande do Sul; such traits mainly included increase in height of the first fertile node (Rubin, 1995). However, efforts to alter adaptive traits, namely reductions in plant height and lodging, were also made for the late maturity groups, (Rubin, 1995), without restraining yield mean increase. In contrast, the yield mean of the early maturity genotypes was higher in three out of the four soybean cropping regions in Rio Grande do Sul at the start of the consolidation of the breeding programs (Table 3). This fact may have induced the breeders to prioritize yield increase for the other two groups. Furthermore, significant genetic gains are harder to obtain in improved germplasm, as was shown by Toledo et al. (1990) by a negative correlation between genetic gain and mean yield.

Another possibility for the lack of genetic progress for the early maturity group is that selection conditions do not permit the discrimination between higher and lower yielding genotypes. In fact, crop management studies suggest that early maturing genotypes yield may be limited by some practices now in use (Board \& Harville 1994; Pires et al., 1998; Ventimiglia et al., 1999). Changing those practices in selection experiments may reveal a higher yield potential variability between early maturing genotypes, allowing the improvement for grain yield of this maturity group. The lack of yield progress shows that the breeding strategies that have been used to obtain cultivars in this group should be reviewed. Otherwise, genotypes of these maturity groups may lose their commercial competitiveness in the State.

The good results obtained in Region I reflected the greater effort placed in this region. Of the four soybean breeding programs in the State in the period assessed, three were located in Region I. Similarly, most of the advanced lines experiments for cultivar indication purposes were also conducted in counties located in this region (Table 2). The maximization of genetic gains in soybean yield in the cropping regions could be reached by restructuring the breeding programs. Trials and selection should be carried out in environments representative of all the cropping diversity of the State. Alternatively, the breeding activities should be regionalized.

The correlation values among the estimated mean annual yields for the soybean cropping regions of the State (Table 4) showed that there was no association between the gains of Region II and the others or between Regions III and IV. However, the estimated annual mean yield obtained in Region I, III and IV correlated positively, although with interme- 
Table 4 - Correlation among the estimated annual mean yield in 20 years, for the four soybean cropping regions of Rio Grande do Sul.

\begin{tabular}{lccccccc}
\hline Cropping region & II & \multicolumn{3}{c}{ III } & IV & \\
\hline I & -0.06 & & NS & 0.56 & $* *$ & 0.56 & $*$ \\
II & & -0.35 & NS & -0.19 & NS \\
III & & & & 0.21 & NS \\
\hline NS - Non-significant. *Significant at the $5 \%$ level of probability. **Significant at the $1 \%$ level of probability.
\end{tabular}

diate values. Selection and evaluation of lines carried out mainly in Region I benefited Regions III and IV moderately, but did not benefit Region II. In the latter region, the gains observed were different from those obtained in all the others, suggesting that the cropping conditions in Region II are completely different from those found in the rest of the State. Region II is characterized by a high probability of drought occurrence during the reproductive stages, when the crop presents a great demand for water. The development of genotypes adapted to Region II should be attained with the selection and evaluation of advanced lines in locations representative of these environmental conditions.

The yield genetic progress shown in this study refers to the gains of the breeding programs, because the data that generated these estimates are from advanced breeding lines and most of them were not recommended for commercial use. Since only the lines with superior performance for yield and other agronomic traits are recommended for commercial use, it is likely that the genetic progress realized by the farmer in the same period was greater. This study focused only on the attained progress in grain yield. Breeding programs usually devote effort to select for adaptive traits such as resistance to biotic and abiotic factors and for traits related to product quality. Thus, a broader evaluation of the success of breeding programs in the State should also consider the alterations that have occurred in these other traits. In the specific case of Rio Grande do Sul, great efforts have been made to incorporate genetic resistance to disease, mainly stem canker (Diaporthe phaseolorum f.sp. meridionalis) and brown stem blight (Phialophora gregata) (Bonato \& Bonato, 2002).

Breeding programs of annual species routinely carry out METs to select new commercial cultivars. The data generated by the METs can be used to obtain extra information relevant for breeding programs with a minimal of cost. Genetic gains can be estimated from the MET data as an alternative to frequently used trials involving varieties representative of different periods, cultivated side-by side, under conditions that simulate the different crop management of each period. Such experiments are necessarily repeated in dif- ferent locations and years, requiring specific allocation of time and resources. Further, there is also a restriction regarding the number of assessed genotypes, which represent a sample of genotypes available in each period.

However, the imbalance, which is intrinsic for METs data sets, has long inhibited the use of the data for purposes other than commercial recommendation of new cultivars. The evolution of computation facilities and the development of robust statistical models for imbalanced data analysis have intensified the use of data obtained by MET. Extra information has been generated that way for several crops such as rice (Breseghello et al., 1998), soybean (Yan et al., 2002; Yan \& Rajcan, 2003), wheat (Trethowan et al., 2002) and ground nuts (Casanoves et al., 2005).

The use of data generated routinely in the evaluation of advanced lines by breeding programs, proposed by Vencovsky et al. (1988), Toledo et al. (1990), St. Martin \& McBlain (1991) and Breseghello et al. (1998), remains little used, mainly because plant breeders do not have the habit of using past data, as animal breeders do. This study serves as an example of the potential of extracting relevant information from existing data, without the need to incur new expenses in carrying out specific trials. The development of statistical models, together with the growing computing capability, permits the use of these data at minimal cost. The formation and maintenance of databanks holding the results of experimentation would also stimulate this practice. The present study contributes to demonstrate the usefulness of the breeding program's testing datasets as a tool to gain knowledge and understanding of the efficacy of the current breeding program.

\section{REFERENCES}

ALLIPRANDINI, L.F.; TOLEDO, J.F.F.; FONSECA JÚNIOR, N.F.; KIHL, R.A.S.; ALMEIDA, L.A. Ganho genético em soja no Estado do Paraná, via melhoramento, no período de 1985/86 a 1989/90. Pesquisa Agropecuária Brasileira, v.28, p.489497, 1993.

BERLATO, M. Exigências bioclimáticas e zoneamento agroclimático no Rio Grande do Sul. In: MIYASAKA S.; MEDINA, J.C. (Ed.) A soja no Brasil. São Paulo: Ital, 1981. p. 187-190. 
BOARD, J.E.; HARVILLE, B.G. A criterion for acceptance of narrow-row culture in soybean. Agronomy Journal, v.86, p.1103-1106, 1994.

BOERMA, H.R. Comparison of past and recently developed soybean cultivars in maturity groups VI, VII, and VIII. Crop Science, v.19, p.611-613, 1979.

BONATO, E.R.; BONATO, A.L.V. Cultivares que fizeram a história da soja no Rio Grande do Sul. Passo Fundo: Embrapa Trigo, 2002. $105 \mathrm{p}$

BRESEGHELLO, F.; MORAIS, O.P.; RANGEL, P.H.N. A new method to estimate genetic gain in annual crops. Genetics and Molecular Biology, v.21, p.551-555, 1998.

BRESEGHELlO, F.; RANGEL, P.H.N.; DE MORAIS, O.P. Yield gain through irrigated rice breeding in the northeast Brazil. Pesquisa Agropecuária Brasileira, v.34, p.399-407, 1999.

CASANOVES, F.; BALDISSARI, J.; BALZARINI, M. Evaluation of multienvironment trials of peanut cultivars. Crop Science, v.45, p.18-26, 2005.

COX, T.S.; SHROYER, J.P; BEN-HUI, L.; SEARS, R.G; MARTIN, T.J. Genetic improvement in agronomic traits of hard red winter wheat cultivars from 1919 to 1987 . Crop Science, v.28, p.756760,1988

KARMAKAR, P.G ; BHATNAGAR, P.S. Genetic improvement of soybean varieties in India from 1969 to 1993 . Euphytica, v.90, p.95-103, 1996.

PENG, S.; LAZÃ, R.C.; VISPERAS, R.M.; SANICO, A.L.; GASSMAN, K.G.; KUSH, G.S. Grain yield of rice cultivars and lines developed in Philippines since 1966. Crop Science, v.40, p.307-314, 2000 .

PIRES, J.L.F.; COSTA, J.A.; THOMAS, A.L. The narrow row increases soybean yield. Pesquisa Agropecuária Gaúcha, v.4, p.183-188, 1998.

RUBIN, S.A.L. Progresso do melhoramento genético da soja no Estado do Rio Grande do Sul. Santa Maria: Universidade Federal de Santa Maria, 1995. 87p. Dissertação (Mestrado).

SAS INSTITUTE. SAS user's guide: statistics; version 5. Cary: SAS Institute, 1985.

SOARES, A.A.; SANTOS, P.G.; DE MORAIS, O.P; SOARES, P.C.; REIS, M.S.; DE SOUZA, M.A. Genetic progress obtained by upland rice in twenty-one years of research in the State of Minas Gerais, Brazil. Pesquisa Agropecuária Brasileria, v.34, p.415-424, 1999.
SPECHT, J.E.; WILLIAMS, J.H. Contribution of genetic technology to soybean productivity: retrospect and propect. In: FEHR, W.R. (Ed) Genetic contributions to yield gains of five major crop plants. Madison: Crop Science Society of America, 1984. p.49-74.

ST. MARTIN, S.K.; McBLAIN, B.A. Procedure to estimate genetic gain by stages in multistage testing programs. Crop Science, v.31, p.1367-1369, 1991.

TOLEDO, J.F.F.; ALMEIDA, L.A.; KIHL, R.A.S.; MENOSSO, O.G. Ganho genético em soja no Estado do Paraná, via melhoramento. Pesquisa Agropecuária Brasileria, v.25, p.89-94, 1990.

TRETHOWAN, R.; GINKEL, M. van; RAJARAN, S. Progress in breeding wheat for yield and adaptation in global drought affected environments. Crop Science, v.42, p.1441-1446, 2002.

USTON, A.; ALLEN, F.L.; ENGLISH, B.C. Genetic progress in soybean of the U.S. midsouth. Crop Science, v.41, p.993-998, 2001.

VENCOVSKY, R.; MORAIS, A.R.; GARCIA, J.C.; TEIXEIRA, N.M. Progresso genético em vinte anos de melhoramento no Brasil. In: CONGRESSO NACIONAL DE MILHO E SORGO, Sete Lagoas, 1986. Anais. Sete Lagoas: Embrapa-CNPMS, 1988. p. 300-306.

VENTIMIGLIA, L.A; COSTA, J.A.; THOMAS, A.L.; PIRES, J.L.F. Soybean yield potential influenced by soil phosphorus content and row spacing. Pesquisa Agropecuária Brasileira, v.34, p.195-199, 1999.

VOLDENG, H.D.; COBER, E.R.; HUME, D.J.; GILLARD, C.; MORRISON, M.J. Fifty-eight years of genetic improvement of short-season soybean cultivars in Canada. Crop Science, v.37, p.428-431, 1997.

YAN, W.; HUNT, L.A.; JOHNSON, P.; STEWARD, G.; LU, X. Onfarm strip trials vs replicated performance trials for cultivar evaluation. Crop Science, v.42, p.385-392, 2002.

YAN, W.; RAJCAN, I.. Prediction of cultivar performance based on single- versus multiple- year test in soybean. Crop Science, v.43, p.549-555, 2003.

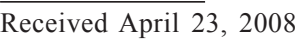

Accepted October 06, 2008 